\title{
HUBUNGAN UMUR KEHAMILAN DENGAN STATUS KESEHATAN GINGIVA PADA IBU HAMIL DI WILAYAH KERJA PUSKESMAS ANDALAS KECAMATAN PADANG TIMUR
}

\author{
Kinanti Fauzin ${ }^{1}$, Hafni Bachtiar ${ }^{2}$, Susi $^{3}$ \\ ${ }^{1}$ Faculty of Dentistry Andalas University \\ ${ }^{2}$ Faculty of Medicine Andalas University \\ ${ }^{3}$ Departemen of Dental Public Health Faculty of Dentristry Andalas University
}

\begin{abstract}
Gingivitis is an inflammation of the soft tissues inoral cavity that invade the free gingival. There are two kinds of etiologies that can cause gingivitis, they are plaque and non-plaque. Pregnant women will have some maternal physiological changes during pregnancy, one of them is the increasing of estrogen and progesterone. It will cause the gingival tissue to react to irritant such as plaque excessively. The aim of this study was to determine the relationship between gestational age and gingival index in pregnant women. This analytic correlation research used cross sectional approach. The gestational age were observed from Mom's and Kid's Health Book. The Gingival Index was observed by using Loe and Silness index to each pregnant woman's oral cavity. Data was analysed by using Chi-square. The study took place in Andalas Public Health Center, from $16^{\text {th }}$ February 2-15 until $26^{\text {th }}$ February 2015. Most of the pregnant women had mild gingivitis, no pregnant women were found with healthy gingiva or severe gingivitis. The result showed that there was no significantly relationship between gestational age and gingival index in pregnant women $(p>0,005)$.
\end{abstract}

Keywords: Gingivitis, gingiva, pregnant women, hormone, gestational age, gingival index.

Affiliasi penulis : 1. Fakultas Kedokteran Gigi Universitas Andalas, 2. Fakultas Kedokteran Universitas Andalas

Korespondensi :Kinanti Fauzin Hundra, email: kinanti.hundra@yahoo.com,

\section{PENDAHULUAN}

Kesehatan menurut World Health Organization (WHO) yaitu suatu keadaan yang sempurna baik fisik, mental, dan sosial serta tidak sedang menderita sakit atau kelemahan. Keadaan rongga mulut selalu berkaitan dengan kesehatan tubuh. Jika terjadi sesuatu pada tubuh, maka tanda - tandanya dapat dilihat dari rongga mulut, begitu juga sebaliknya. Rongga mulut merupakan tempat hidup berbagai jenis bakteri, mulai dari bakteri yang baik sampai bakteri yang berbahaya. Rongga mulut juga rentan untuk mengalami infeksi dan peradangan. Oleh karena itu menjaga kesehatan rongga mulut sangatlah penting karena mulut yang sehat akan mencerminkan tubuh yang sehat. ${ }^{1}$

Wanita memiliki kebutuhan yang unik akan kesehatan. Wanita memiliki masa - masa khusus dalam hidupnya yang tidak dialami laki - laki yaitu pubertas, kehamilan dan menopause. Wanita harus menjaga kesehatan lebih dari biasanya selama masamasa tersebut, karena adanya perubahan hormonal yang akan berdampak ke seluruh tubuhnya. ${ }^{2}$ 
Kehamilan merupakan peristiwa yang penting dalam kehidupan seorang wanita dan keluarganya untuk memperoleh keturunan. Kehamilan adalah suatu proses fisiologis yang dapat menimbulkan perubahan-perubahan pada perempuan, baik secara psikologis maupun fisiologis. ${ }^{3}$

Adapun salah satu perubahan fisiologi pada ibu hamil yaitu terjadinya perubahan jumlah hormon - hormon tertentu. Perubahan hormon ini akan berdampak ke seluruh tubuh termasuk rongga mulut. Penelitian menunjukkan bahwa terjadi peningkatan kadar hormon estrogen dan progesteron dalam saliva ibu hamil selama kehamilan. ${ }^{4}$

Pada trimester pertama kadar hormon progesteron dalam saliva ibu hamil adalah sekitar $250 \mathrm{pg} / \mathrm{ml}$, dan meningkat menjadi dua kali lipat pada trimester kedua, dan menjadi enam kali lipat pada trimester ketiga. Kadar hormon estradiol dalam saliva ibu hamil pada trimester pertama adalah sekitar 0,9 $\mathrm{pg} / \mathrm{ml}$, dan meningkat empat kali lipat pada trimester kedua, lalu meningkat menjadi 20 kali lipat pada trimester ketiga. $^{5}$ Peningkatan hormon akan berhubungan dengan kerentanan jaringan terhadap peradangan, misalnya jaringan dalam rongga mulut (Harpenau, 2013). Sehingga kehamilan merupakan salah satu faktor resiko penyebab penyakit jaringan periodontal misalnya gingivitis. ${ }^{6}$

Tujuan penelitian ini adalah untuk mengetahui hubungan umur kehamilan dengan status kesehatan gingival pada ibu hamil. Penelitian dilakukan pada ibu hamil di wilayah kerja Puskesmas Andalas Kecamatan Padang Timur. Umur kehamilan dilihat dari buku KIA yang dibawa oleh ibu hamil. Status kesehatan gingiva diukur menggunakan Indeks Gingiva Loe dan Silness.

\section{METODE}

Jenis penelitian yang dilakukan adalah penelitian analytic correlation dengan pendekatan cross-sectional. Penelitian dilakukan di Puskesmas Andalas Kecamatan Padang Timur pada bulan Februari 2015. Populasi dalam penelitian ini adalah ibu hamil yang tercatat di wilayah kerja Puskesmas Andalas. Sampel dalam penelitian ini berjumlah 66 orang yang memenuhi kriteria inklusi dan eksklusi. Kriteria inklusi dari penelitian ini adalah ibu hamil yang tidak merokok, tidak menderita penyakit dan meminum obat yang dapat mempengaruhi jaringan periodontal, dan yang tidak memakai alat prosthodonti dan orthodonti. Kriteria eksklusi dari penelitian ini adalah ibu hamil dengan kondisi $\mathrm{OH}$ yang buruk. 
Alur penelitian dimulai dengan melihat dan mencatat data pribadi ibu hamil seperti nama, umur, dan usia kehamilan lewat buku KIA. Lalu dilakukan observasi untuk menentukan apakah $\mathrm{OH}$ ibu hamil ini buruk atau tidak. Setelah dinyatakan $\mathrm{OH}$ ibu hamil tidak buruk, selanjutnya dilakukan pemeriksaan Indeks Gingiva Loe dan Silness. Caranya adalah dengan Lakukan inspeksi untuk melihat warna, bentuk, dan kontur gingival, kemudian lakukan palpasi untuk melihat tekstur dan konsistensi gingiva. Jalankan probe periodontal ke dalam saku gusi mulai dengan gigi indeks 16, 11, 24, 36, 31, 44 (memakai system FDI) dari sisi mesial terus melingkari gigi. Berikan skor berdasarkan kondisi yang terdapat pada gingiva pada masing - masing sisi: ${ }^{7}$

\begin{tabular}{cl} 
Tabel 1 & Keadaan Gingiva \\
\hline $\begin{array}{c}\text { Sko } \\
\mathbf{r}\end{array}$ & $\begin{array}{l}\text { Gingiva normal: tidak ada peradangan, } \\
\text { tidak ada perubahan warna, dan tidak ada } \\
\text { perdarahan }\end{array}$ \\
\hline 1 & $\begin{array}{l}\text { Peradangan ringan: terlihat ada sedikit } \\
\text { perubahan warna dan sedikit edema, } \\
\text { tetapi tidak ada perdarahan saat probing }\end{array}$ \\
\hline 2 & $\begin{array}{l}\text { Peradangan sedang: warna kemerahan, } \\
\text { adanya edema dan terjadi perdarahan } \\
\text { saat probing }\end{array}$ \\
\hline 3 & $\begin{array}{l}\text { Peradangan berat: warna merah terang } \\
\text { atau merah menyala, adanya edema, } \\
\text { ulserasi, cenderung berdarah spontan }\end{array}$ \\
\hline
\end{tabular}

Skor di atas adalah untuk satu sisi gigi, lalu skor keempat sisi dijumlahkan, kemudian dibagi empat untuk mendapatkan skor satu gigi. Setelah dilakukan penghitungan terhadap enam gigi indeks, keenam skor yang diperoleh dijumlahkan, lalu dibagi enam untuk mendapatkan skor Indeks Gingiva individu, kemudian tentukan kategori gingiva berdasarkan tabel berikut: ${ }^{7}$ Skor di atas adalah untuk satu sisi gigi, lalu skor keempat sisi dijumlahkan, kemudian dibagi empat untuk mendapatkan skor satu gigi. Setelah dilakukan penghitungan terhadap enam gigi indeks, keenam skor yang diperoleh dijumlahkan, lalu dibagi enam untuk mendapatkan skor Indeks Gingiva individu, kemudian tentukan kategori gingiva berdasarkan tabel berikut: $^{7}$

Tabel 2

\begin{tabular}{ll}
\hline \multicolumn{1}{c}{ Kriteria } & \multicolumn{1}{c}{ Skor } \\
\hline Sehat & 0 \\
\hline Gingivitis Ringan & $0,1-1,0$ \\
\hline Gingivitis Sedang & $1,1-2,0$ \\
\hline Gingivitis Parah & $2,1-3.0$ \\
\hline
\end{tabular}

\section{HASIL}

Penelitian dilakukan pada $66 \mathrm{ibu}$ hamil di wilayah kerja Puskesmas Andalas Kecamatan Padang Timur. Berdasarkan penelitian yang telah dilakukan, diperoleh informasi tentang karakteristik sampel berdasarkan umur sebagai berikut: 


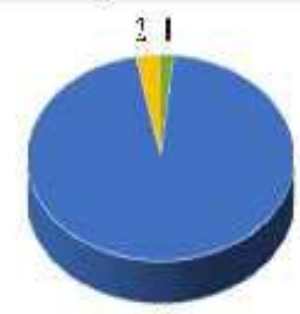

6.3

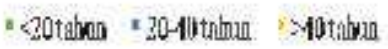

\section{Grafik 1 : Distribusi Sampel} Berdasarkan Umur

Berdasarkan grafik diketahui umur sampel yang paling banyak adalah berkisar 20 - 40 tahun yaitu sebanyak 63 orang $(95,4 \%)$.

Distribusi sampel berdasarkan umur kehamilan dapat dilihat pada grafik berikut:

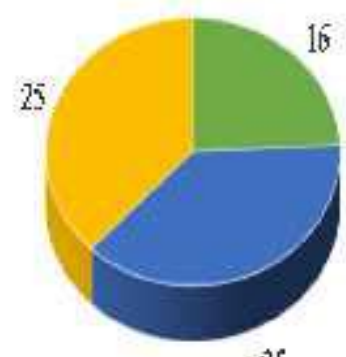

is

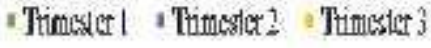

Distribusi sampel berdasarkan status kesehatan gingiva dapat dilihat pada grafik berikut:

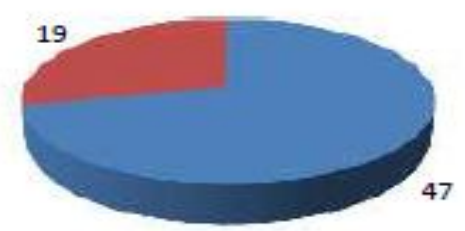

Gingivitis Ringan Gingivitis Sedang

Grafik 3 : Distribusi Sampel berdasarkan Status Kesehatan Gingiva
Data dari grafik 3 menunjukkan bahwa kategori status kesehatan gingiva yang paling banyak

ditemukan adalah gingivitis ringan sebanyak 47 orang (71,2\%). Tidak ditemukan sampel dengan kategori status kesehatan gingiva yang sehat dan parah.

Selanjutnya dilakukan analisa bivariat antara usia kehamilan dengan status kesehatan

gingiva. Hasil yang diperoleh adalah sebagai berikut:

\begin{tabular}{|c|c|c|c|c|c|c|c|}
\hline \multirow{2}{*}{ UK } & \multicolumn{3}{|c|}{ Status Kesehatan Gingiva } & \multicolumn{2}{|c|}{ Total } & \multirow{2}{*}{ P } \\
\cline { 2 - 6 } & \multicolumn{2}{|c|}{ Ringan } & \multicolumn{2}{|c|}{ Sedang } & \multicolumn{2}{|c|}{} \\
\cline { 2 - 6 } & $f$ & $\%$ & $f$ & $\%$ & $f$ & $\%$ & \\
\hline TM 1 & 13 & $81,3 \%$ & 3 & $\begin{array}{c}18,8 \\
\%\end{array}$ & 16 & $24 \%$ & \multirow{2}{*}{0,495} \\
\hline TM 2 & 16 & $64,0 \%$ & 9 & $\begin{array}{c}36,0 \\
\%\end{array}$ & 25 & $38 \%$ & \\
\hline TM 3 & 18 & $72,0 \%$ & 7 & $\begin{array}{c}28,0 \\
\%\end{array}$ & 25 & $38 \%$ & \\
\hline Total & 47 & $71,2 \%$ & 19 & $\begin{array}{c}28,8 \\
\%\end{array}$ & 68 & $\begin{array}{c}100 \\
\%\end{array}$ & \\
\hline
\end{tabular}

Tabel 1 : Hubungan Usia Kehamilan dengan Status

Kesehatan Gingiva pada Sampel

Keterangan

UK : Usia Kehamilan

TM : Trimester

Data dari tabel 5.1 menunjukkan bahwa kategori status kesehatan gingiva yang paling banyak

ditemukan adalah gingivitis ringan pada trimester satu yaitu sebanyak 81,3\%. Kategori gingivitis sedang paling banyak ditemukan pada trimester dua yaitu sebanyak $36 \%$. Pada penelitian ini tidak ditemukan sampel dengan status 
kesehatan gingiva kategori gingiva sehat dan gingivitis parah. Hasil uji statistik diperoleh nilai $\mathrm{p}$ sebesar 0,495 ; artinya nilai $\mathrm{p}>0,05$; maka dapat disimpulkan bahwa tidak ada hubungan antara usia kehamilan dengan status kesehatan gingiva pada sampel (terdapat hubungan yang tidak signifikan antara usia kehamilan dengan status kesehatan gingiva pada sampel).

\section{PEMBAHASAN}

Pada penelitian ini didapatkan bahwa 71,2\% dari 66 sampel memiliki status kesehatan gingiva berupa gingivitis ringan, sisanya mengalami gingivitis sedang. Berdasarkan usia kehamilannya, sampel dengan usia kehamilan trimester satu, $81,3 \%$ diantaranya mengalami gingivitis ringan dan 18,8\% diantaranya mengalami gingivitis sedang. Pada sampel dengan usia kehamilan trimester dua ditemukan bahwa 64\% diantaranya mengalami gingivitis ringan dan 36\% diantaranya mengalami gingivitis sedang. Pada kelompok ibu hamil dengan usia kehamilan trimester tiga, 72,0\% diantaranya mengalami gingivitis ringan dan $28 \%$ mengalami gingivitis sedang. Hal ini menunjukkan bahwa gingivitis terjadi pada seluruh sampel meski dengan kondisi $\mathrm{OH}$ yang baik. Hasil ini sejalan dengan teori yang menyatakan bahwa kehamilan dapat memicu terjadinya gingivitis meski dengan kondisi $\mathrm{OH}$ yang baik. $^{7}$

Hasil penelitian menunjukkan adanya peningkatan keparahan gingivitis dari kelompok usia kehamilan trimester satu ke kelompok usia kehamilan trimester dua, kemudian terjadi penurunan pada kelompok usia kehamilan trimester tiga. Hasil ini sejalan dengan teori yang menyatakan bahwa mikroflora pada subgingiva meningkat saat usia kehamilan memasuki trimester kedua, lalu menurun saat masuk trimester ketiga sampai setelah melahirkan. ${ }^{8}$ Tidak ditemukan sampel dengan gingivitis parah, karena sampel dengan $\mathrm{OH}$ buruk sudah dieksklusikan.

Hasil penelitian ini menunjukkan bahwa secara statistik tidak ada hubungan yang signifikan antara usia kehamilan dengan status kesehatan gingiva pada ibu hamil. Hal ini disebabkan karena kadar hormon estrogen dan progesteron mencapai puncaknya pada trimester tiga, ${ }^{5}$ sedangkan tingkat keparahan gingivitis ditemui paling tinggi pada trimester dua, ${ }^{9}$ dengan kata lain tidak ada hubungan yang signifikan antara peningkatan kadar hormon estrogen dan progesteron dalam sulkus gingiva ibu hamil dengan tingkat keparahan gingivitis. ${ }^{5}$ Pada trimester dua ditemukan peningkatan jumlah Prevotella intermedia yang merupakan salah satu 
mikroorganisme penting yang menjadi etiologi

gingivitis, jumlah mikroorganisme tersebut akan menurun saat mencapai usia kehamilan trimester tiga, hal ini yang diperkirakan menjadi penyebab meningkatnya keparahan gingivitis pada trimester dua ${ }_{8}^{8}$ Gingivitis dengan keparahan yang berbeda terjadi pada semua sampel yang diperiksa, yaitu ibu hamil yang memiliki $\mathrm{OH}$ baik dan $\mathrm{OH}$ sedang dan sudah memenuhi kriteria inklusi lain. Tidak ditemukan ibu hamil dengan status kesehatan gingiva yang parah. Penelitian ini sejalan dengan teori yang ada, yang menyatakan bahwa tidak ada hubungan yang signifikan antara peningkatan keparahan gingivitis dengan kadar hormon dalam saliva ibu hamil. ${ }^{5}$ Gingivitis kehamilan disebabkan oleh bakteri yang ada dalam plak, sama seperti penyebab gingivitis pada wanita yang tidak hamil. Kehamilan hanya akan meningkatkan respon gingiva terhadap bakteri dalam plak. Perubahan klinis pada gingiva tidak akan terjadi tanpa keterlibatan faktor lokal seperti plak. ${ }^{10}$

Hasil penelitian ini sejalan dengan ini hasil penelitian Rakchanol et al yang menyatakan bahwa kejadian gingivitis pada ibu hamil cukup tinggi, yaitu lebih dari $80 \%$ ibu hamil yang diteliti menderita gingivitis. ${ }^{11}$ Penelitian ini juga sejalan dengan penelitian yang dilakukan oleh Ganesh et al yang menemukan bahwa dari 208 ibu hamil yang diteliti kesehatan gingivanya, $49 \%$ ibu hamil mengalami gingivitis ringan dan $47 \%$ ibu hamil mengalami gingivitis sedang.

\section{KESIMPULAN}

Berdasarkan penelitian yang telah dilakukan dapat disimpulkan bahwa secara statistik tidak ada hubungan yang signifikan antara umur kehamilan dengan status kesehatan gingiva pada ibu hamil

\section{KEPUSTAKAAN}

1. Rahmadhan, Ardyan Gilang. 2010. SerbaSerbi Kesehatan Gigi dan Mulut. Bukune : Jakarta, p 13-14.

2. Yoto, Hendro. Anindita. Mintjelungan, Christy. 2013. Gambaran Gingivitis pada Ibu Hamil di Puskesmas Tuminting Kecamatan Tuminting Kota Manado. Jurnal e-gigi 1(2). Bagian Penyakit Mulut FKG Universitas Sam Ratulangi. Manado, p 2

3. Hamilton, Mary Persis. 1995. Dasar Dasar Keperawatan Materinitas Edisi 6. EGC : Jakarta, p 59-60.

4. Prawirohardjo, Sarwono. 2010. Ilmu Kebidanan. PT Bina Pustaka Sarwono Prawirohardjo : Jakarta, p 59.

5. Figuero et al. 2010. Gingival changes during pregnancy : Influence of hormonal variations on clinical and immunological parameters. J Clin Periodontal, University of Madrid. Vol 37. Spanyol, p 223

6. Carranza. 2002. Clinical Periodontology 9th Edition. W.B. Saunders Company: USA, p 65 -70, p 205 - 220, p 270.

7. Dibart, Serge. Dietrich, Thomas (2010). Practical Periodontal Diagnosis and Treatmant Planning. Blackwell Publishing, USA, p 19.

8. Lafaurie, Gloria Inés. 2011. Gingival Tissue and Pregnancy. School of Dentistry Bogota, Colombia, p 101-104 
9. Gursoy, Mervi. 2012. Pregnancy and Periodontium a clinical, microbiological, and enzymological approach via a longitudinal study. J. of Period. Univ. of Turku, p 20-35.

10. Carranza. 2006. Clinical Periodontology 10th Edition. W.B. Saunders Company: USA, p 12-20.

11. Rakchanok, Noochpoung. Amporn, Dejpitak. Yoshida, Yoshitoku. Rashid, Harun. Sakamoto, Junichi. 2010. Dental Caries And Gingivitis Among Pregnant And Non-Pregnant Women In Chiang Mai, Thailand. J Chiang Mai PH Office : Thailand, p 43- 45 